\title{
Identification of Co-1 Anthracnose Resistance and Linked Molecular Markers in Common Bean Line A193
}

\author{
Azucena Mendoza, Fernando Hernández, Sanjuana Hernández, Department of Genetic Engineering, CIN- \\ VESTAV, Unidad Irapuato, Apdo. Postal 629, Irapuato, Guanajuato, Mexico; Daniel Ruíz, Institución de En- \\ señanza e Investigación en Ciencias Agrícolas, Colegio de Posgraduados, Montecillo, Texcoco, Mexico; Octavio \\ Martínez de la Vega, Department of Genetic Engineering, CINVESTAV, Unidad Irapuato, Apdo. Postal 629, \\ Irapuato, Guanajuato; Gustavo Mora, Institución de Enseñanza e Investigación en Ciencias Agrícolas, Colegio de \\ Posgraduados, Montecillo, Texcoco; Jorge Acosta, Instituto Nacional de Investigaciones Forestales, Agrícolas y \\ Pecuarias, (INIFAP), Campo Experimental Valle de México, Chapingo, Edo. de Mexico, México; and June Simpson, \\ Department of Genetic Engineering, CINVESTAV, Unidad Irapuato, Apdo. Postal 629, Irapuato, Guanajuato
}

\begin{abstract}
Mendoza, A., Hernández, F., Hernández, S., Ruíz, D., Martínez de la Vega, O., Mora, G., Acosta, J., and Simpson, J. 2001. Identification of Co-1 anthracnose resistance and linked molecular markers in common bean line A193. Plant Dis. 85:252-255.

Phaseolus vulgaris line A193 has been shown to be widely resistant to Colletotrichum lindemuthianum, including race 1472, one of the most virulent races of $C$. lindemuthianum characterized. Resistance to C. lindemuthianum race 1472 in P. vulgaris line A193 was investigated in segregating $\mathrm{F}_{2}$ and $\mathrm{F}_{2.3}$ populations from a cross between A193 and Flor de Mayo Bajio (a commercial cultivar highly susceptible to C. lindemuthianum). Resistance to 1472 in A193 was determined to be conditioned by a single dominant gene. Inoculation of crosses between A193 and cultivars Michigan Dark Red Kidney and Perry Marrow with race 1472 suggest that resistance in A193 is conditioned by the Co-1 gene. Inoculation of the cross A193 $\times$ Perry Marrow with $C$. lindemuthianum race 2, demonstrated that resistance to race 2 in Perry Marrow is also conditioned by a single dominant gene and is distinct to resistance in A193 or Michigan Dark Red Kidney. Three AFLP markers (ECAG/MACC-1, EACA/MAGA-2, EAGG/MAAC-8) linked in repulsion to the Co- 1 locus were identified by screening the $\mathrm{A} 193 \times$ Flor de Mayo $\mathrm{F}_{2}$ population with 314 random amplified polymorphic DNA, amplified fragment length polymorphism, and restriction fragment length polymorphism markers. The two most closely linked markers should be useful in marker-assisted selection for $\mathrm{Co}-1$.
\end{abstract}

Anthracnose caused by the fungal pathogen, Colletotrichum lindemuthianum (Sacc. et Magn.) Scrib. on the common bean, Phaseolus. vulgaris L., can be a devastating disease under the right environmental conditions. Providing resistant germ plasm is the best way to combat the disease. This task is complicated, however, by the pathogen's variability $(4,10,14,18)$. The Andean and Middle-American gene pools are the two major gene pools recognized in $P$. vulgaris (9). Recent reports $(4,18,10)$ have suggested a strong correlation between the source of germ plasm (Andean or Middle-American gene pools) and the capacity to resist different races of C. lindemuthianum. Combining resistance genes from both gene pools, within a single cultivar should provide a wider and

Corresponding author: J. Simpson

E-mail: jsimpson@irapuato.ira.cinvestav.mx

Accepted for publication 9 October 2000.

Publication no. D-2000-1222-01R

(C) 2001 The American Phytopathological Society prolonged resistance to $C$. lindemuthianum within a given region $(14,13,23)$.

Most investigations have concentrated on characterizing resistance genes present in Middle-American cultivars, leading to the identification of at least nine different resistance genes (7). Analysis of Andean germ plasm, however, has been lacking with the only fully characterized resistance gene being the first anthracnose resistance gene identified (15): the A or Co- 1 gene.

Breeding programs at INIFAP (National Institute for Investigation in Forestry, Agriculture, and Animal Husbandry) in Mexico have utilized the Andean line A193 from the International Center for Tropical Agriculture (CIAT). A193 is widely resistant to $C$. lindemuthianum from field trials carried out by CIAT in Colombia (2). The genetic basis of the resistance in line A193, however, was previously unknown.

This study sought to determine the basis of the resistance to $C$. lindemuthianum in line A193, whether the source of resistance was different from previously characterized resistance genes, and to identify molecular markers linked to the resistance that could be used in breeding programs involving Middle-American germ plasm.

\section{MATERIALS AND METHODS}

Plant material. Segregating $\mathrm{F}_{2}$ and $\mathrm{F}_{2.3}$ populations of a cross between A193 and Flor de Mayo (FM), a commercial cultivar commonly used in Mexico and susceptible to a wide variety of races of the pathogen were examined. The line A193 was obtained from CIAT and was produced from a cross between ICA Pijao (G21721, Middle American, MA) and Mulato Gordo (G6474, Andean, A). Flor de Mayo Bajio was obtained from INIFAP, Mexico, and was developed from a cross between Flor de Mayo (landrace, MA) and Amanda (A). Seeds were scarified, washed with a $1 \%$ solution of sodium hypochlorite and distilled water, then sown at a depth of $2 \mathrm{~cm}$ in plastic pots containing a 2:1 mixture of Sunshine/vermiculite. Seeds were left to germinate in darkness for 5 days before transplanting the germinated seedlings to plastic bags with $5 \mathrm{~kg}$ of sterilized soil. Three types of plant material were used for inoculations in different experiments: A193 $\times$ Flor de Mayo $F_{2}$ mature plants (preflowering stage, i.e., when first buds appear); A193 × Flor de Mayo $F_{2.3} 7$ - to 10-day-old seedlings with only primary leaves; and A193 × Michigan Dark Red Kidney $($ MDRK) and A193 × Perry Marrow $\mathrm{F}_{2}$ detached primary leaves.

Fungal isolates. Samples of $C$. lindemuthianum were obtained from leaves or pods of naturally infected bean plants found in the field. Infected plant tissue was placed on acidified potato dextrose agar (PDA; Difco, Detroit, MI). Colonies showing growth and morphology typical of C. lindemuthianum were transferred to fresh acidified PDA where they were maintained until sporulation was achieved. A suspension of spores was prepared from these cultures and dispersed on fresh acidified PDA. After 24 to $48 \mathrm{~h}$ individual germinated spores were transferred to fresh acidified medium. A colony produced from a single spore was maintained as a pure isolate for inoculation of plant material. Classification of races or pathotypes of the isolates has been described previously (10).

Inoculation of plant material. Mature plants were grown to the preflowering 
stage, then spores of the required race were suspended at a concentration of $1.5 \times 10^{6}$ conidia per $\mathrm{ml}$ and sprayed on stems and the underside of bean leaves. Inoculated plants were incubated under conditions of 95\% humidity for 8 to 10 days and then evaluated for symptoms.

For 7- to 10-day-old seedlings, spores from each isolate were suspended at a concentration of $1.5 \times 10^{6}$ conidia per $\mathrm{ml}$ and sprayed onto the underside of the primary leaves. Inoculated plants were grown under $95 \%$ humidity at $20^{\circ} \mathrm{C}$ for 8 to 10 days and then evaluated for symptoms.

Detached leaves were infected as described by $\mathrm{Tu}$ (20). Fully opened primary leaves were removed close to the peduncle and surface sterilized in $1 \%$ hypochlorite for 1 to $2 \mathrm{~min}$, then rinsed in sterile distilled water. Leaves were then placed face down on moist filter paper. Direct contact with filter paper was avoided by placing two microscope slides between the leaves and the filter paper. Fungal spores were applied to the underside of each leaf at a concentration of $7.0 \times 10^{6}$ conidia per $\mathrm{ml}$. Inoculated leaves were incubated at $20^{\circ} \mathrm{C}$ and $95 \%$ humidity for 7 days before evaluating disease symptoms. Symptoms on all materials were evaluated on a five-point scale as described previously (6) 0 to $2=$ resistant and 3 to $4=$ susceptible.

Statistical analysis. Individual plants were classified as resistant (either showing no visible symptoms or small hypersensitive flecks) or susceptible (showing sporulating necrotic lesions). Frequencies for each class were tested for goodness-of-fit to theoretical ratios using chi-square tests. Ten to 15 plants of each $\mathrm{F}_{3}$ family were inoculated, and based on the number of susceptible plants observed the family was classified as homozygous resistant, heterozygous resistant, or homozygous susceptible and used to confirm the $\mathrm{F}_{2}$ genotype.

Molecular marker analysis. Restriction fragment length polymorphism (RFLP) analysis was performed using standard Southern blotting techniques. Probes were obtained from E. Vallejos (University of Florida) (21) and labeled by either random priming or polymerase chain reaction using ${ }^{32} \mathrm{P}$ dCTP. Random amplified polymorphic DNA (RAPD) analysis was carried out using the following protocol: the reaction mixture consisted of Taq DNA polymerase buffer (10X-100 mM Tris-HCL, pH 8, 15 $\mathrm{mM} \mathrm{MgCl} 2500 \mathrm{mM} \mathrm{KCl}), 400 \mu \mathrm{M}$ of each dNTP, $0.2 \mathrm{mM}$ oligonucleotide primer, 15 ng of genomic DNA from P. vulgaris, and 1 unit of Taq polymerase (Boehringer Mannheim) in a final volume of $25 \mu$ l. The amplification reaction was carried out in a Perkin Elmer 9600 thermocycler (Foster City, CA) programmed for $2 \min$ at $94^{\circ} \mathrm{C}$, followed by 40 cycles of $1 \mathrm{~min}$ at $94^{\circ} \mathrm{C}, 2$ min at $37^{\circ} \mathrm{C}, 2 \mathrm{~min}$ at $72^{\circ} \mathrm{C}$, one cycle of 7 min at $72^{\circ} \mathrm{C}$ then holding at $4^{\circ} \mathrm{C}$. Amplified products were separated on $1.2 \%$ agarose gels and observed under UV light follow- ing staining with ethidium bromide. Primers used were kits A-J, Operon Technology, Alameda, CA.

Amplified fragment length polymorphism (AFLP) analysis, conducted as described by Vos et al. (22), used three selective nucleotides and either end labeling the EcoRI primer in the second selective amplification with $\mathrm{g}^{32} \mathrm{P}$ dATP using $\mathrm{T} 4$ kinase or using fluorescently labeled primers. Fragments obtained using fluorescently labeled primers were separated and detected using an Applied Biosystems ABI370 automatic sequencer and Genescan and Genotyper software (Perkin Elmer, Foster City, CA). Molecular marker linkage analysis was carried out using Joinmap 2.0 (19).

\section{RESULTS}

In order to determine the interaction between the $P$. vulgaris genotypes used in this study and $C$. lindemuthianum, the genotypes of interest were inoculated with nine different races of $C$. lindemuthianum (Table 1). The races of $C$. lindemuthianum used were previously determined by inoculation on a set of differential cultivars and identified using binary nomenclature as described by Pastor-Corrales (17). Genotype A193 was resistant to all the races tested with the exception of race 2 . Flor de Mayo was susceptible to all races tested with the exception of 2 and 264. MDRK showed the same reaction as A193, whereas Perry Marrow was resistant to all nine races (Table 1).

Race 1472 was chosen to inoculate the segregating $\mathrm{F}_{2}$ and $\mathrm{F}_{2.3}$ populations because it is one of the most aggressive isolates

Table 1. Reaction of Phaseolus vulgaris germplasm to different races of Colletotrichum lindemuthianum $^{\mathrm{a}}$

\begin{tabular}{lccccccccc}
\hline & \multicolumn{10}{c}{ Race of C. lindemuthianum } \\
\cline { 2 - 10 } Plant genotypes & $\mathbf{0}$ & $\mathbf{2}$ & $\mathbf{2 5 6}$ & $\mathbf{2 6 4}$ & $\mathbf{3 2 0}$ & $\mathbf{3 9 2}$ & $\mathbf{4 4 8}$ & $\mathbf{1 0 8 8}$ & $\mathbf{1 4 7 2}$ \\
\hline A193 & $\mathrm{R}$ & $\mathrm{S}$ & $\mathrm{R}$ & $\mathrm{R}$ & $\mathrm{R}$ & $\mathrm{R}$ & $\mathrm{R}$ & $\mathrm{R}$ & $\mathrm{R}$ \\
Flor de Mayo & $\mathrm{S}$ & $\mathrm{R}$ & $\mathrm{S}$ & $\mathrm{R}$ & $\mathrm{S}$ & $\mathrm{S}$ & $\mathrm{S}$ & $\mathrm{S}$ & $\mathrm{S}$ \\
MDRK & $\mathrm{R}$ & $\mathrm{S}$ & $\mathrm{R}$ & $\mathrm{R}$ & $\mathrm{R}$ & $\mathrm{R}$ & $\mathrm{R}$ & $\mathrm{R}$ & $\mathrm{R}$ \\
Perry Marrow & $\mathrm{R}$ & $\mathrm{R}$ & $\mathrm{R}$ & $\mathrm{R}$ & $\mathrm{R}$ & $\mathrm{R}$ & $\mathrm{R}$ & $\mathrm{R}$ & $\mathrm{R}$ \\
\hline
\end{tabular}

${ }^{\mathrm{a}} \mathrm{R}=$ Resistant; $\mathrm{S}=$ Susceptible; MDRK = Michigan Dark Red Kidney.

Table 2. Results of inoculation of A193 $\times$ Flor de Mayo with race $1472^{\text {a }}$

\begin{tabular}{lcccccc}
\hline Plant genotypes & Generation & Resistant & Susceptible & Expected ratio & $\boldsymbol{X}_{\mathbf{2}}$ & $\boldsymbol{P}$ \\
\hline $\mathrm{A} 193$ & $\mathrm{P}_{1}$ & 50 & 0 & & & \\
$\mathrm{FM}$ & $\mathrm{P}_{2}$ & 0 & 50 & & & \\
$\mathrm{~A} 193 \times \mathrm{FM}$ & $\mathrm{F}_{1}$ & 2 & 0 & & & \\
$\mathrm{~A} 193 \times \mathrm{FM}$ & $\mathrm{F}_{2}$ & 96 & 36 & $3: 1$ & 0.36 & 0.55 \\
$\mathrm{~A} 193 \times \mathrm{FM}$ & $\mathrm{F}_{2.3}$ & $57 \mathrm{R} / 116 \mathrm{Rr}$ & 64 & $1: 2: 1$ & 0.52 & 0.77 \\
\hline
\end{tabular}

${ }^{a} \mathrm{RR}=$ homozygous resistant; $\mathrm{Rr}=$ heterozygous resistant; FM = Flor de Mayo.

Table 3. Results of inoculation of A193 $\times$ MDRK/A193 $\times$ PM with race $1472^{\text {a }}$

\begin{tabular}{lccc}
\hline Plant genotype & Generation & Resistant & Susceptible \\
\hline A193 & $\mathrm{P}_{1}$ & 20 & 0 \\
MDRK & $\mathrm{P}_{2}$ & 20 & 0 \\
A193 $\times$ MDRK & $\mathrm{F}_{2}$ & 100 & 0 \\
A193 $\times$ PM & $\mathrm{F}_{2}$ & 100 & 0 \\
\hline
\end{tabular}

${ }^{\mathrm{a}} \mathrm{MDRK}=$ Michigan Dark Red Kidney; PM = Perry Marrow. characterized to date, specifically infecting (idde-American cultivars, and shows a Flor de Mayo Bajío. (Table 2). The results $F_{2}$ population support a segregaindividuals suggesting that resistance to 1472 in A193 is due to a single domianalysis of the $\mathrm{F}_{23}$ families which showed Rr:rr, (Table 2)

tance to $C$. lindemuthianum has been fully characterized in $P$. vulgaris germ plasm ining to the Andean gene pool. The cultivar MDRK. A193 derives from Angerm plasm and like MDRK is sus(Table 1). Perry Marrow is another differin Andean germ itional RK and A193 $\times$ Perry Marrow. No inceptible individuals were observed after Perry Marrow is conditioned by resistance Co-I locus. Analysis of the with race 2 (Table 4 ) shows that a single dominant gene present in Perry Marrow to race 2

To identify molecular markers linked to the $\mathrm{Co}-1$ gene that could potentially be a good fit to a segregation ratio of $1: 2: 1$,

gels and observed under UV light follow- 
used in a marker-assisted selection program, the $\mathrm{F}_{2}$ population was analyzed using 19 RFLP, 247 AFLP (219 radioactively labeled, 28 fluorescently labeled), and 47 RAPD markers. From this analysis, 12 linkage groups of at least four linked markers were obtained using Joinmap 2.0 (data not shown). The grouping file was obtained using logarithm of odds (LOD) 5 , and for recombination and mapping analysis a LOD threshold of 0.001 and a recombination threshold of 0.499 were used. This generated a linkage group with the resistance gene (Fig. 1). Three AFLP markers from oligonucleotide combinations EcoRICAG/MseI ACC, EcoRIAGG/MseIAAC (radioactively labeled), and EcoRIACA/ MseIAGA (fluorescently labeled) were tightly linked to the $\mathrm{Co}-1$ locus. The set of $P$. vulgaris differential cultivars used to distinguish races of $C$. lindemuthianum was analyzed using the most tightly linked marker, EACA/MAGA-2, at $2.7 \mathrm{cM}$ from

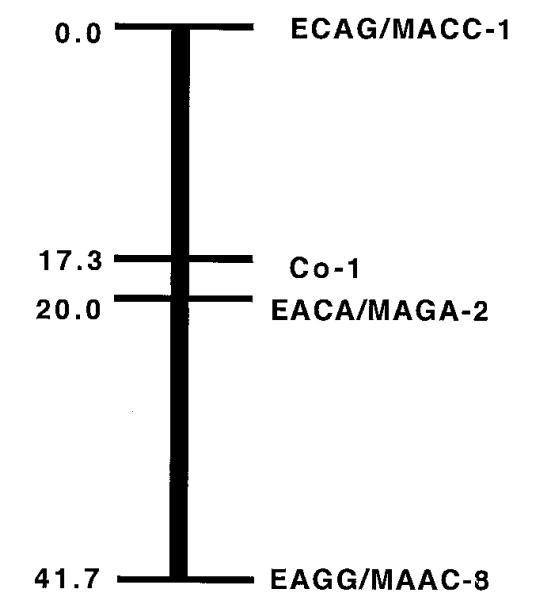

Fig. 1. Linkage group containing the Co- 1 locus and three amplified fragment length polymorphism (AFLP) molecular markers. AFLP's are labeled with the selective nucleotides of the primers used to detect them. E refers to the EcoRI primer, M to the MseI primer. The distance in $\mathrm{cM}$ is indicated on the lefthand side of the figure.
Co-1 (Fig. 2). The band corresponding to EACA/MAGA-2 was present in all cultivars of Middle-American origin (Michelite, Cornell 49-242, Widusa, Mexico 222, PI 207262, TO, TU, AB136, and G2333) but absent in cultivars of Andean origin (MDRK, Perry Marrow, and Kaboon).

\section{DISCUSSION}

The results in Table 1 reflect the relationship between specific $C$. lindemuthianum races and the origin of $P$. vulgaris germ plasm. All races except race 2 are specific to Middle-American germ plasm. Flor de Mayo is resistant to only one race specific to Middle-American germ plasm, race 264, and to the Andean-specific race 2. In contrast, the Andean genotypes A193, MDRK, and Perry Marrow are resistant to all Middle-American specific races, but A193 and MDRK are susceptible to the Andean-specific race 2. Perry Marrow although also an Andean genotype is resistant to all races including race 2 , suggesting that the basis of resistance is different in Perry Marrow in comparison to A193 and MDRK.

Race 1472, isolated in Mexico, was chosen to study the pattern of inheritance of resistance in the segregating $\mathrm{F}_{2} / \mathrm{F}_{2.3}$ populations of a cross between A193 and Flor de Mayo, because it gives a differential reaction between the two lines and is one of the most aggressive isolates of $C$. lindemuthianum infecting four differential cultivars of Middle-American origin in the set of 12 (PI 207262, TO, Mexico 222, and $\mathrm{AB} 136)$. Results of the inoculation on the segregating $F_{2}$ and $F_{2.3}$ populations show that resistance to race 1472 in A193 is due to the action of a single dominant gene. This agrees with previous reports where resistance to different strains of $C$. lindemuthianum was also shown to be due to dominant genes acting either independently or epistatically $(15,3,1,7)$. The failure to find any susceptible individuals in the A193 × MDRK and A193 × Perry Marrow populations inoculated with race 1472 suggests that resistance to race 1472 in A193, MDRK, and Perry Marrow is conditioned by alleles at the $\mathrm{Co}-1$ gene.

Race 2, also isolated in Mexico, was chosen to inoculate the A193 $\times$ Perry Marrow population because it infects MDRK known to carry $\mathrm{Co}-1$, but not Perry Marrow. Race 2 was used since races infecting Andean germ plasm are rare in Mexico and no races of this type had been characterized by us at the time of carrying out the experiments. The segregation ratio of $3: 1$ resistant to susceptible plants in the A193 $\times$ Perry Marrow cross inoculated with race 2 suggests that Perry Marrow carries a different form of resistance. Resistance to race 2 in Perry Marrow may be due to the presence of a second independent gene for anthracnose resistance or because the $\mathrm{Co}-1$ allele present in Perry Marrow provides resistance to both race 1472 and race 2 . The latter explanation would agree with the hypothesis that an allelic series exists at the $\mathrm{Co}-1$ locus (16). The existence of a cluster of tightly linked anthracnose resistance genes, however, has also been reported $(7,8)$ and shown to be associated with genes from both the Middle-American and Andean $P$. vulgaris gene pools. Genes for resistance to $C$. lindemuthianum have been localized to linkage groups B4 and

Table 4. Results of inoculation of A193 $\times$ Perry Marrow with race $2^{\mathrm{a}}$

\begin{tabular}{lcccccc}
\hline Material & Generation & Resistant & Susceptible & Expected ratio & $\boldsymbol{X}_{\mathbf{2}}$ & $\boldsymbol{P}$ \\
\hline $\mathrm{A} 193$ & $\mathrm{P}_{1}$ & 0 & 5 & & & \\
$\mathrm{PM}$ & $\mathrm{P}_{2}$ & 5 & 0 & & & \\
$\mathrm{~A} 193 \times \mathrm{PM}$ & $\mathrm{F}_{2}$ & 112 & 38 & $3: 1$ & 0.008 & 0.93 \\
\hline
\end{tabular}

${ }^{\mathrm{a}} \mathrm{PM}=$ Perry Marrow.

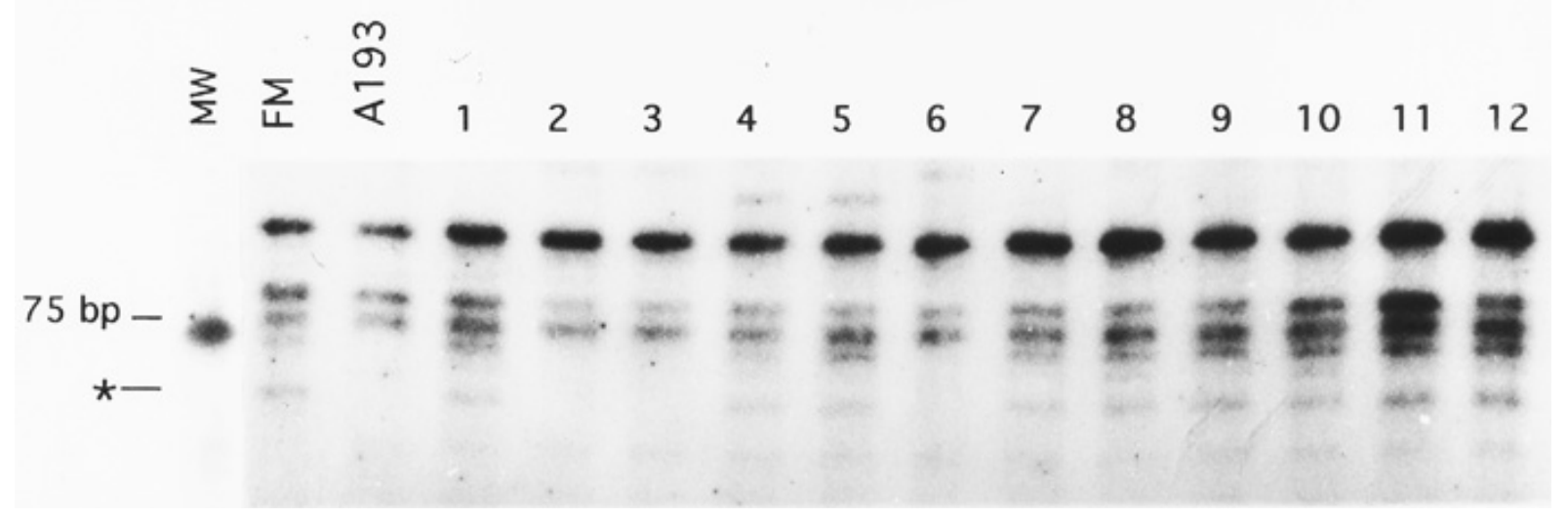

Fig. 2. Analysis of Phaseolus vulgaris anthracnose differential cultivars with EACA/MAGA-2. MW, Molecular weight marker; FM, Flor de Mayo; 1, Michelite; 2, Michigan Dark Red Kidney; 3, Perry Marrow; 4, Cornell 49-242; 5, Widusa; 6, Kaboon; 7, Mexico 222; 8, P.I. 207262; 9, TO; 10, TU; 11, AB136; 12, G2333. The asterisk indicates the band corresponding to EACA/MAGA-2. 
B11 on the $P$. vulgaris integrated map, $(5,8)$; however, it has not been possible to assign $\mathrm{Co}-1$ to either of these regions. The possibility that resistance genes for $C$. lindemuthianum are associated with resistance genes for other pathogens also remains to be determined.

Three AFLP markers were found to be closely linked to the $\mathrm{Co}-1$ resistance gene in A193. All the markers in the study are linked in repulsion to the resistance locus, i.e., the recessive allele (absence of band) segregates with resistance. Likewise Young and Kelly (24) identified a RAPD marker in repulsion with the $\mathrm{Co}-1$ locus. Although 815 molecular markers (between this study and that of Young and Kelly [24]) have been analyzed to identify markers linked to Co-1, all four markers identified to date, (three in this study, one in Young and Kelly [24]) are in repulsion to Co-1. Furthermore, the marker most tightly linked to Co-1 in this study is capable of distinguishing between Middle-American and Andean germ plasm. Young and Kelly (24) also observed this tendency with a RAPD marker tightly linked to $\mathrm{Co}-1$ although their results differ from ours in relation to Middle-American cultivar G2333. Whereas they observed the absence of the RAPD marker in this cultivar indicating the presence of $\mathrm{Co}-1$, the presence of the band for EACA/MAGA-2 in this study would support absence of $\mathrm{Co}-\mathrm{I}$ in G2333. Taken together these findings may indicate some form of genomic rearrangement in the region surrounding the $\mathrm{Co}-1$ locus which may be associated with germ plasm of Andean origin.

The markers found to be flanking $\mathrm{Co}-1$ at distances of $2.7 \mathrm{cM}$ and $17.3 \mathrm{cM}$ in this study, should be useful in marker-assisted selection for the introgression of $\mathrm{Co}-\mathrm{l}$ into susceptible germ plasm. Previous reports have demonstrated increased efficiency of selection when markers linked in repulsion are used to select for pest or fungal resistance since individuals homozygous at the resistance locus can be directly selected whereas selection for the presence of a coupled marker is complicated by the presence of heterozygotes which are difficult to identify $(11,12)$.

Although it was hoped to identify a new source of resistance to $C$. lindemuthianum within Andean germ plasm, the fact that the Co- 1 locus was again identified in A193 underlines the need for a wider study of resistance in the Andean gene pool. It may be the case that very few independent resistance genes exist in the Andean gene pool or that variability is associated with distinct alleles at a few loci. The finding that race 2 resistance in Perry Marrow is at least due to a different allele at the Co-1 locus if not to an independent gene sug- gests that alternative sources of resistance do exist. The task now is to characterize these sources. If indeed the resistance is due to a different allele at $\mathrm{Co}-1$ it would be interesting, eventually, to characterize both the A193 and the Perry Marrow alleles at the molecular level in order to determine the changes which lead to the specific recognition of different races of $C$. lindemuthianum.

\section{ACKNOWLEDGMENTS}

The work was funded by CONACyT Mexico under grant number 3517P-B, SIHGO Mexico under grant number 98/2761 ALIM-19/97, and The Foundation Guanajuato Produce. A. Mendoza acknowledges support from CONACyT and CONCyTEG for Ph.D studies. D. Ruiz and F. Hernandez acknowledge support from CONACyT for M.Sc. and B.Sc. studies respectively. We thank L. Herrera-Estrella for critical reading of the manuscript and J. Kelly (Michigan State University) for many helpful insights and for the kind gift of $C$. lindemuthianum race 2 . We also thank M. González and R. Rodríguez for useful discussions and the two referees who reviewed the manuscript and provided helpful suggestions.

\section{LITERATURE CITED}

1. Alzate-Marin, A. L., Baía, G. S., de Paula Júnior, T. J., de Carvalho, G. A., de Barros, E. G., and Moreira, M. A. 1997. Inheritance of resistance in common bean differential cultivar AB136. Plant Dis. 81:996-998.

2. Beebe, S. E., and Pastor-Corrales, M. A. 1991. Breeding for Disease Resistance. Pages 561-617 in: Common Beans: Research for Crop Improvement. A. van Schoonhoven and O. Voysest, eds. C. A. B. International, Wallingford, U.K.

3. Cardenas, F., Adams, M. W., and Anderson, A. L. 1964. The genetic system for reaction of field beans (Phaseolus vulgaris L.) to infection by three physiologic races of Colletotricum lindemuthianum. Euphytica 13:178186.

4. Fabre, J.-V., Julien, J., Parisot, D., and Dron, M. 1995. Analysis of diverse isolates of Colletotrichum lindemuthianum infecting common bean using molecular markers. Mycol. Res. 99:429-435.

5. Freyre, R., Skroch, P. W., Geffroy, V., AdamBlondon, A-F., Shirmohamadali, A., Johnson, W. C., Llaca, V., Nodari, R. O., Pereira, P. A., Tsai, S-M., Tohme, J., Dron, M., Nienhuis, J., Vallejos, C. E., and Gepts, P. 1998. Towards an integrated linkage map of common bean. 4: Development of a core linkage map and alignment of RFLP maps. Theor. Appl. Genet. 97:847-856

6. Garrido-Ramirez, E. R., and Romero-Cova, S. 1989. Identificación de razas de Colletotrichum lindemuthianum (Sacc. Y Magn.) Scrib. En México y búsequeda de resistencia genética a este hongo. Agrociencia 77:139156.

7. Geffroy, V., Sicard, D., de Olveira, J. C. F., Sévignac, M., Cohen, S., Gepts, P., Neema, C., Langin, T., and Dron, M. 1999. Identification of an ancestral resistance gene cluster involved in the coevolution process between Phaseolus vulgaris and its fungal pathogen Colletotrichum lindemuthianum. Mol. PlantMicrobe Interact. 12:774-784.

8. Geffroy, V., Sévignac, M., De Olveira, J. F. C., Fouilloux, G., Skroch, P., Thoquet, P., Gepts, P., Langin, T., and Dron, M. 2000. In- heritance of partial resistance against Colletotrichum lindemuthianum in Phaseolus vulgaris and co-localization of quantitative trait loci with genes Involved in specific resistance. Mol. Plant-Microbe Interact. 13:287296.

9. Gepts, P. 1988. A Middle American and an Andean Common Bean Gene Pool. Pages 375-390 in: Genetic Resources of Phaseolus Beans. P. Gepts, ed. Kluwer Academic Publishers, Dordrecht, Netherlands.

10. González, M., Rodríguez, R., Zavala, M. E., Jacobo, J. J., Hernández, F., Acosta, J., Martínez, O., and Simpson, J. 1998. Characterization of Mexican isolates of $C$. lindemuthianum using differential cultivars and molecular markers. Phytopathology 88:292-299.

11. Haley, S. D., Afanador, L., and Kelly, J. D. 1994. Selection for monogenic pest resistance traits with coupling and repulsion-phase RAPD markers. Crop Sci. 34:1061-1066.

12. Johnson, E., Miklas, P. N., Stavely, J. R., and Martínez-Cruzado, J. C. 1995. Coupling- and repulsion-phase RAPDs for marker assisted selection of PI 181996 rust resistance in common bean. Theor. Appl. Genet. 90:659664.

13. Kelly, J. D. 1995. Use of randomly amplified polymorphic DNA markers in breeding for major gene resistance to plant pathogens. J. Am. Soc. Hortic. Sci. 30:461-465.

14. Kelly, J. D., Afanador, L., and Cameron, L. S. 1994. New races of Colletotricum lindemuthianum in Michigan and implications in dry bean resistance breeding. Plant Dis. 78:892-894.

15. McRostie, G. P. 1919. Inheritance of anthracnose resistance as indicated by a cross between a resistant and a susceptible bean. Phytopathology 9:141-148.

16. Melotto, M., Awale, H. E., and Kelly, J. D. 1999. An allelic series at the Co- 1 locus for anthracnose resistance in common bean Annu. Rep. Bean Improv. Coop. 42:9-10.

17. Pastor-Corrales, M. A. 1991. Estandarización de variedades diferenciales y designación de razas de Colletotrichum lindemuthianum. Phytopathology 81:694.

18. Sicard, D., Michalakis, Y., Dron, M., and Neema, C. 1997. Genetic diversity and pathogenic variation of Colletotrichum lindemuthianum in the three centers of diversity of its host Phaseolus vulgaris. Phytopathology 87:807-813.

19. Stam, P. 1993. Construction of integrated genetic linkage maps by means of a new computer package: Joinmap. Plant J. 3:739744.

20. Tu, J. C. 1986. A detached leaf technique for screening beans (Phaseolus vulgaris L.) in vitro against anthracnose Colletotrichum lindemuthianum. Can. J. Plant Sci. 66:805-809.

21. Vallejos, C. E., Sakiyama, N. S., and Chase, C. D. 1992. A molecular marker-based linkage map of Phaseolus vulgaris L. Genetics 131:733-740.

22. Vos, P., Hogers, R., Bleeker, M., Reijans, M. Van de Lee, T., Hornes, M., Frijters, A., Pot, J., Peleman, J., Kuiper, M., and Zabeau, M 1995. AFLP: A new technique for DNA fingerprinting. Nucl. Acids Res. 23:4407-4414.

23. Young, R. A., and Kelly, J. D. 1996. Characterization of the genetic resistance to Colletotrichum lindemuthianum in common bean differential cultivars. Plant Dis. 80:650-654

24. Young, R. A., and Kelly, J. D. 1997. RAPD markers linked to three major anthracnose resistance genes in common bean. Crop Sci. 37:940-946. 